\title{
Spastic paraplegia-nephritis-deafness syndrome
}

INSERM

\section{Source}

INSERM. (1999). Orphanet: an online rare disease and orphan drug data base. Spastic paraplegia-nephritis-deafness syndrome. ORPHA:2820

Spastic paraplegia-nephritis-deafness syndrome is a complex form of hereditary spastic paraplegia characterized by prog ressive, variable spastic paraplegia associated with bilateral sensorineural deafness, intellectual disability, and progressive nephropathy. There have been no further descriptions in the literature since 1988. 